\title{
Computer-aided instruction on an MBA programme
}

\author{
Jonathan Miller \\ Graduate School of Business, University of Cape Town
}

The Graduate School of Business of the University of Cape Town (UCT) recently acquired a powerful mini-computer with interactive terminals and a range of educational and business software. This paper applies a particular model of the learning process in order to choose the most effective computer-based teaching methods for the MBA programme. It is argued that this choice must take into account characteristics of the learner, the learning environment, the material being learned and the stage of the learning process. These elements and the current status of computer-aided instruction on the UCT MBA programme are described and basic policy guidelines are presented.

S. Atr. J. Bus. Mgmt. 1982, 13: $121-125$

Die nagraadse bestuurskool aan die Universiteit van Kaapstad het onlangs 'n kragtige minirekenaar met interaktiewe terminale en ' $n$ verskeidenheid van opvoedkundige en sake-sagteware bekom. In hierdie artike! word ' $n$ besondere model van die leerproses toegepas vir die keuse van die mees doeltreffende rekenaar-gebaseerde onderrigmetodes vir die MBA-program. Die redenasie is dat die eienskappe van die leerder, die leeromgewing, die materiaal wat aangeleer word, en die stadium in die leerproses alles by so 'n keuse in ag geneem moet word. Hierdie elemente en die huidige stand van sake met betrekking tot rekenaar-ondersteunde onderrig in die MBA. program van die Universiteit van Kaapstad word beskryf, en basiese beleidsriglyne word voorgestel.

S.Afr. Tydskr. Bedryfsl. 1982, 13: 121-125

Paper presented at S.A. Conference on Computers in Education, Stellenbosch. Based on an unpublished paper submitted to the Department of Accounting, UCT, in part-fulfilment of the degree of M.Com. (BDP).

\section{Introduction}

The degree of Master of Business Administration at the University of Cape Town is of fered by its Graduate School of Business (GSB). For some time the GSB has had its own small in-house computer as well as remote access to the large university facility, but the nature of these facilities has not allowed extensive use of computers for teaching purposes. The recent acquisition of a powerful minicomputer with ease of use and interactive capabilities, and compatible with a wide range of educational and business software, has presented major opportunities to apply computer support on a broad front.

The objective of this paper is to describe the status of Computer-Aided Instruction (CAI) at the GSB and to present a particular model of the learning process which allows effective policy decisions and the objective selection of computer-based teaching methods.

In the next section basic hardware and software issues are noted and six modes of computer usage for teaching purposes are described. The third section presents a particular model of the learning process and argues that the effective use of computers depends on characteristics of the learner, the learning environment, the material being learned and the stage of the learning process. Section four describes the structure and content of the MBA programme at the GSB and presents the objectives and nature of current and planned computer-aided instruction on the programme. The final section contains broad policy guidelines for on-going management of CAI at the Business School.

\section{Basic elements for implementing computer-aided} instruction

\section{Hardware}

The successful incorporation of computer-aided instruction into an educational programme clearly depends to a large extent on hardware facilities. The choice between micros, minis and main-frames is the first difficult step. Chambers and Sprecher ${ }^{1}$ state for instance:

'The advent of the micro-computer has resulted in heated debates concerning the relative merits of CAI systems supported by large-scale, powerful computer configurations as contrasted to the CAI capabilities of the micro-computers'.

And in interpreting Hawkins's major international survey, Barker ${ }^{2}$ notes:
University University of Cape Town, Rondebosch 7700 , Republic of South Africa 
'Respondents had equally mixed feelings about whether the source of computational and instructional power should be derived from a large machine, micro/mini, or a computer network'.

Micro-computers offer a very inexpensive entry point, are portable, frequently have facilities such as colour graphics, and eliminate wasteful usage of central storage facilities. Large main-frames have the advantage of economies of scale, central control, capacity for large scale packages and programming effort, and central data-base development and management.

The modern mini-computer, however, offers a possible compromise between these two extremes. Much software originally designed for main-frames is now available for mini-computers. Minis approach micros in terms of ease of use, and yet compare with main-frames in terms of storage capacity and processing power. Mini-computers generally cost substantially less than main-frames.

This is the route taken by UCT's Graduate School of Business which recently acquired a PRIME mini-computer together with 12 student terminals, an $80 \mathrm{mb}$ discdrive, an 800 bpi tapedrive and a $3001 \mathrm{pm}$ printer. The GSB also has an RJE link to the main university UNIVAC.

Important considerations in making this decision were

- cost of the facility

- operating system in terms of student use

- interactive terminal capability

- availability of business and educational software

- ability to emulate large business computer environments.

\section{Software}

The development and sharing of quality CAI materials has been termed 'the single most critical issue in CAI today'. 1 There has also been criticism of 'the massive accumulation of instructional software produced by relatively inexperienced programmers . . . which is then marketed as a ready made source of solutions to educational problems'. ${ }^{3}$

Fortunately, at least at the university level, there are now organizations that review and disseminate proven courseware, CONDUIT being a prominent example. ${ }^{4}$ Authors are assisted in programming educational material, which is subsequently reviewed, documented and adapted for ease of transfer. GSB has acquired several packages in this way.

Business schools are also in a fortunate position since much basic business software can be used directly in business education. For instance, the use of financial modelling packages, data base management systems and statistical systems is described ahead. Business schools may also find it useful to access public sources such as the Johannesburg Stock Exchange.

\section{Modes of computer usage}

CAI facilities such as those described above can be used in several different ways on a teaching programme. Six broad modes of CAI are considered in this paper: tutorial, drill and practice, problem-solving, simulation, inquiry and gaming.

In tutorial mode material is presented for the first time. A fact may be stated, elaborated in a few sentences, and the student then given a problem to work out or blanks to fill in before being allowed to move to the next item.

In drill and practice mode, the student is led through a series of examples of increasing complexity or differing nature, in linear or branching fashion depending on the result of student responses.

Problem-solving mode on the computer implies the provision of a computer and a programming language via which students are encouraged to tackle and solve problems. BASIC is the best known language in this context.

In simulation mode a pre-programmed model is provided. The student is able to access the model and manipulate it by varying input data, selecting different equations, carrying out sensitivity analysis and in general exploring the simulated reality that the model represents.

Inquiry mode makes use of a database and a database management system such that students have rapid and generalized access to the available data.

Finally, in this context gaming may be regarded as an extension of simulation where the simulation model has the added element of competition. Typically, student teams might represent companies in a competitive market place and make a series of decisions over simulated time. Effectiveness of the decisions might be measured by market share or profitability, as well as verbal or written presentations.

In subsequent sections the use of these different modes of CAI will be discussed within the context of the chosen learning model and its application at the Graduate School of Business.

\section{A learning model and the selection of instructional techniques at the graduate school}

Introduction

Given today's multiplicity of instructional techniques and facilities, institutions need to choose carefully or risk submerging students in a haphazard smorgasbord of conventional lectures, programmed texts, study modules, films, videotapes, written assignments, computer simulations, etc.

Rockart and Scott Morton ${ }^{5}$ have proposed an operational model of the learning process that allows the instructor to choose rationally and effectively between different instructional techniques. Based on the so-called 'experiential learning model', 6 this model will be briefly described and then applied to the selection of computer-based techniques in general and to the GSP situation in particular.

\section{The learning model}

In Figure 1, knowledge is categorized as facts (definitions, specific items and ideas), skills (procedures and their application), established concepts (theories, hypotheses and assertions that are well enough accepted to warrant minimal learned debates), and frontier concepts (recent developments and long-standing unresolved issues open to debate). It is postulated that learning proceeds through four stages: new knowledge must be acquired, embedded, integrated and then tested. (This is related to the StimulusResponse models ${ }^{7}$ and Gestalt models of learning. The Gestalt concepts of insightful learning and transfer of knowledge relate closely to the above stages of embedding, integrating and testing.)

The model can also be represented as a $4 \times 4$ matrix 


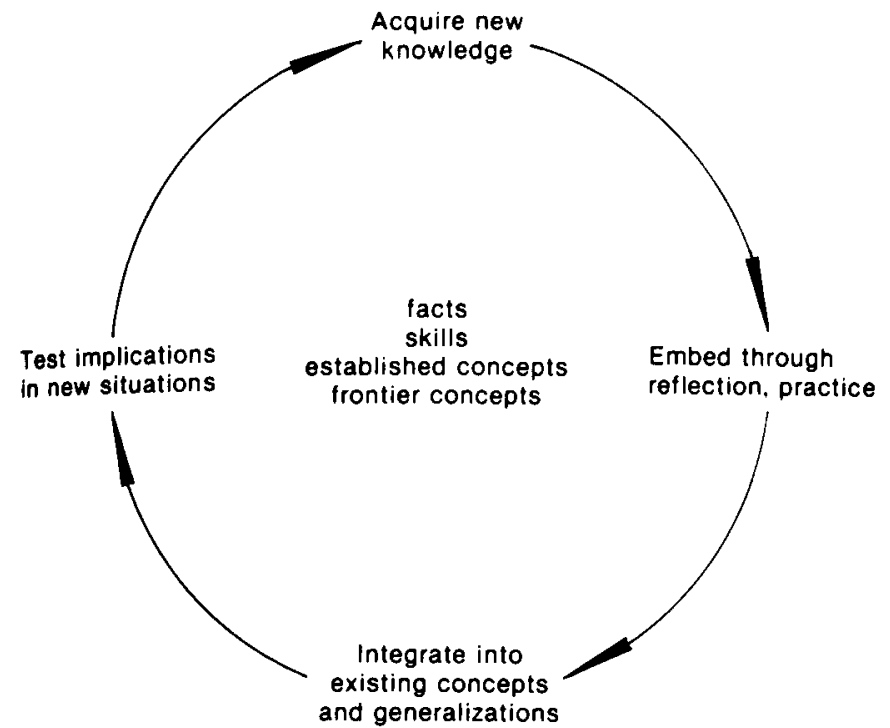

Flgure 1 The learning model

in which each of the 16 cells is the stage in the learning of a particular category of knowledge. Reporting on extensive research, Rockart and Scott Morton conclude that, for most effective learning, different cells in the matrix have different requirements such as rapid feedback, rich learning environment, and accessibility to past data. A wide range of audio, visual, written and computer techniques are then classified in terms of their 'learning attributes' and correlated with the cells in the matrix.

CAI techniques have particular and sometimes unique attributes. Table 1 focuses on some of these and shows the connection between learning requirements and learning techniques.

Non-computer-based techniques are more closely associated with the acquisition of new knowledge. Because of the large percentage of all students' time devoted to acquiring facts and skills, attributes such as ease of use, low cost and decentralized availability are desirable. At least at the time of the study $(1971-73)$, conventional textbooks, programmed texts and study modules possessed these attributes in far greater measure than, for instance, computer-based tutorial techniques. Acquisition of established and frontier concepts calls for the presentation of complex new information, dealing with unstructured material, rapid inclusion of new items and individualized attention. The lecture and guided class discussion are prominent in terms of these attributes. (The reader is referred to the cited work for a much greater appreciation of the depth and breadth of the original study.)

\section{The GSB environment}

The selection of learning techniques depends as much on the learning environment and the learner as it does on the material being taught.

MBA students at UCT's GSB go through a rigorous selection procedure. They are chosen on the basis of their response to a detailed application questionnaire, referees' reports, a lengthy interview and performance on the General Management Admissions Test (GMAT). While the successful applicants come from a variety of educational and working backgrounds, they almost all have prior university degrees and all have some working experience (the average is five years). The selection process ensures that the student body is intelligent, mature and strongly self-motivated.

The MBA programme itself is very intense. Whether it is the one-year full-time, or the two-year part-time programme, 18 individual courses must be completed and a lengthy dissertation submitted. It is expected that each of the 280 two-hour class lectures/discussions will be preceeded by at least the same amount of private study of prescribed readings and cases as well as small group discussions of pre-specified issues and problems.

Because of the pace at which the MBA programme runs and the amount of material to be covered, a rigorous structure has to be imposed and each student must keep to it. There are only limited opportunities for individual coaching, and there is no time for leisurely practice of skills learned. As in business itself, students have to manage their time continuously and choose between the various demands upon them.

Within this context the judicious use of computer technology holds great promise. While the learning model and practical observation indicate that the traditional learning process - readings, case analysis, group and classroom debate - will continue to be most effective for acquisition of knowledge on the MBA programme, it is at the stages of embedding, integrating and testing the new knowledge, that the special attributes of CAI come to the fore.

Given appropriate hardware and courseware, all the techniques shown in Table 1 can be employed at various stages of learning on individual courses. Where there is no time for more than a few manual or hand calculator exercises in finance or statistics, computer-based drill and practice and problem-solving enable more, and more realistic examples to be tackled to embed and integrate new skills and concepts. Where complex time-dependent business relationships need understanding, the opportunity to experiment with computerized simulation models, exploring the events of several months or years in a matter of minutes, underlines the unique benefits of computer

Table 1 Link between learning requirements and CAl techniques

\begin{tabular}{|c|c|c|}
\hline $\begin{array}{l}\text { Stage of learning/ } \\
\text { type of knowledge }\end{array}$ & $\begin{array}{l}\text { Learning requirement/ } \\
\text { important attribute }\end{array}$ & $\begin{array}{l}\text { Prominent CAI } \\
\text { technique }\end{array}$ \\
\hline $\begin{array}{l}\text { embed facts, skilis, } \\
\text { established concepts }\end{array}$ & $\begin{array}{l}\text { rapid, objective } \\
\text { feedback }\end{array}$ & drill and practice \\
\hline \multirow[t]{2}{*}{$\begin{array}{l}\text { embed, integrate and } \\
\text { test facts, skills, } \\
\text { established concepts }\end{array}$} & $\begin{array}{l}\text { individualized } \\
\text { learning, } \\
\text { learner control, } \\
\text { assist structured } \\
\text { clerical tasks }\end{array}$ & problem-solving \\
\hline & $\begin{array}{l}\text { present structure } \\
\text { clearly, } \\
\text { allow data } \\
\text { manipulation, } \\
\text { provide rich } \\
\text { environment }\end{array}$ & $\begin{array}{l}\text { simulation and } \\
\text { gaming }\end{array}$ \\
\hline $\begin{array}{l}\text { embed and integrate } \\
\text { frontier concepts }\end{array}$ & $\begin{array}{l}\text { fast access to } \\
\text { relevant data and } \\
\text { existing models }\end{array}$ & inquiry systems \\
\hline
\end{tabular}


modelling. Where the implications of alternative economic theories can be tested by analysing banks of economic data using a variety of econometric formulae, the special advantages of inquiry systems are clear.

Perhaps because of the business orientation, maturity and determination of the typical MBA student, the challenge of tackling the computer and at the same time enhancing the learning process has led to considerable enthusiasm at GSB. The problem is not to promote CAI within the student body, but to control it. In the next section, the academic courses on the MBA programme are sketched and present and planned computer support is described.

\section{Application of computer-aided instruction Academic structure of the MBA programme}

Figure 2 shows 20 or so courses that are offered on the MBA programme at UCT. With the exception of the 'technical report' course which requires students to write a dissertation, all the courses employ the traditional lecture format and range in length from 10 to 20 two-hour lectures.

Figure 2 shows certain important features of the overall structure of the programme. At the centre of the diagram are four of the so-called 'core' courses. These courses are offered in the first term and provide a compulsory grounding on which subsequent courses will build. At the next level are further core courses offered in the second and third terms, in general building on those courses shown closest to them in the figure. The third level consists of 'elective' or 'special field' courses from which students can choose. Since these electives build on and deepen the knowledge already gained, the choice will depend on past performance and interest in the associated core courses, as well as future career objectives.

Finally, on the perimeter of the diagram are core and elective courses taken towards the ends of the year. These are broadly based 'integrative' courses intended to pull together the knowledge and concepts covered in previous courses.

As the MBA progresses, the general emphasis shifts from instructors' input, theoretical issues and 'acquisition of facts and skills', to student output (projects, assignments, presentations), practical business applications and 'testing of frontier concepts'. The programme ends with the technical report which is a major individual exercise in applied research.

\section{Incorporation of CAI}

Elements of CAI have already been incorporated on several courses at GSB and a number of new packages are currently being loaded and tested. The source for much of this material has been CONDUIT. ${ }^{5}$

In the financial area, hands-on training in the basic skill of financial modelling is offered early in the year. The basic teaching is via the Interactive Financial Planning System (IFPS), although SIMPLAN and EPS are also available. Acquisition of this skill provides the basis for subsequent use of computer models in management accounting, corporate finance and advanced finance. The objective is to improve the integration of accounting and financial concepts by allowing instructors to set problems of realistic size and complexity. Initially students might use the computer to manipulate pre-written financial models. Subsequently they might build their own models to assist in the solution of financial cases.

The sequence of courses including statistical method, operations management and advanced management science is supported by software such as the Statistical Package for the Social Sciences (SPSS), Quantitative Experimental Analysis, Computer Models in Operations Management and Linear Programming. The problems and cases that are set, start with simple interactive exercises in basic statistics and progress through the year via more complex cases in operations management to the fully fledged formulation and solution of optimization models using linear programming. The objective is to embed the basic procedures by

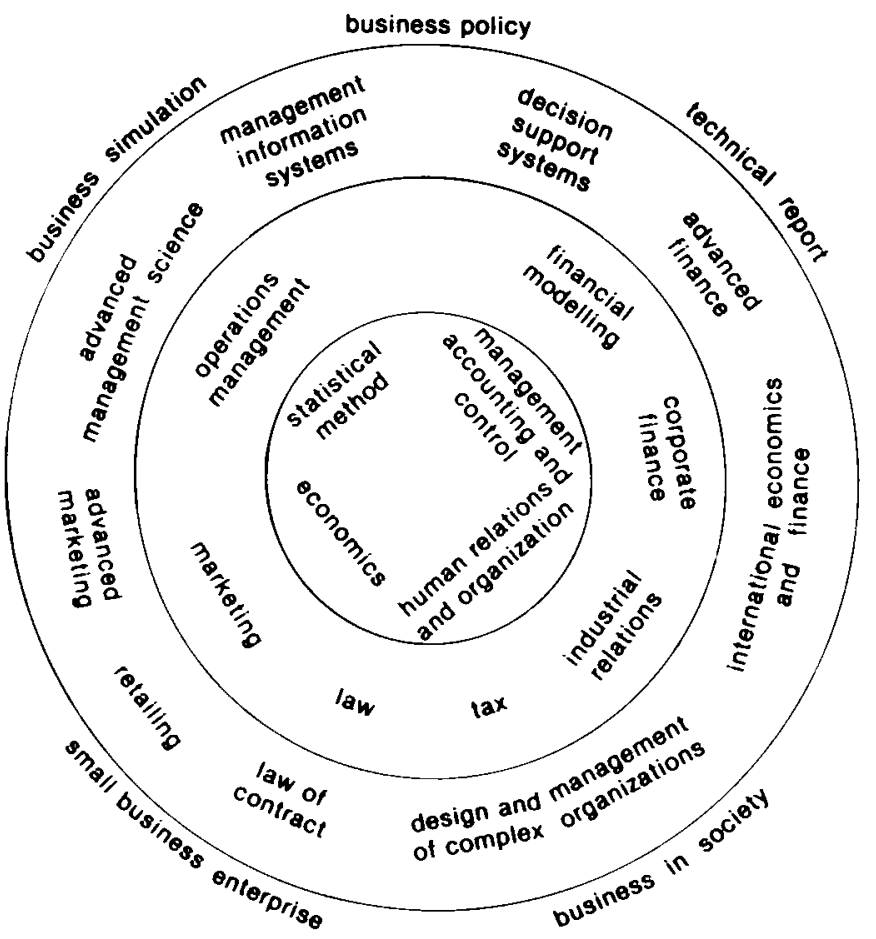

Figure 2 MBA Programmme - course structure 
providing meaningful problems and quick feedback and ultimately to improve the integration of quantitative concepts by providing a richer environment for exploration.

Economics and marketing concepts are supported by a series of policy games in macro-economics, a diffusion game and a marketing game incorporating advanced techniques such as perceptual mapping and conjoint analysis. These facilities assist in the initial acquisition of new skills and concepts and eventually provide a sophisticated environment in which students can test their insight into advanced management techniques.

The course in decision-support systems is a new one and by its very nature will require a computer-based environment. Use will be made of the supplier's data base management and inquiry facilities supplemented by other modelling and analytical software to simulate real world requirements for computerized decision-support.

An imporant opportunity for MBA students to test their knowledge of various business skills and concepts is afforded by the computerized business simulation run late in the year. During a few days, management teams compete with each other for profits and market share over two years of simulated time - an exercise in quantitative business analysis as well as in group decision-making under stress.

Finally the GSB computing facilities are of course available for students to use on their technical reports. Programming can be undertaken in BASIC and FORTRAN for those problems not amenable to the use of the higher level packages.

In the next section, the role of CAI at UCT's Business School is summarized and some of the important policy guidelines pertinent to this activity are noted.

\section{Pollcy guidelines and conclusions}

The policy guidelines for computer-aided instruction discussed here are aimed at ensuring the most effective use of the special features of CAI and avoiding the risk of confusing MBA students with a welter of new-fangled techniques. By their nature these guidelines are specific to the GSB environment and each other institution will find it has its unique set of requirements too.

- CAI should be an adjunct to the existing teaching process

In terms of the overall GSB environment, and the nature of the individual-group-class structure, CAI should be used selectively in support of the traditional teaching process, rather than supplementing whole courses or eliminating instructors.

- CAI should progress in step with the overall MBA process, and technological barriers should be minimized.

The MBA programme comprises a progressive broadening and deepening of business knowledge. The use of computer techniques should reflect this process, starting with straightforward interactive tasks and progressing to more complex problem-solving and open-ended activities such as simulation studies and modelling. MBA students should not be forced to program or learn complicated computer procedures.
- CAI elements should be selected primarily on the basis of their unique benefits.

The special attributes of CAI such as the ability to telescope time, ability to present structure, provision of a rich environment, support for structured, clerical tasks and for unstructured data manipulation, and opportunities for rapid feedback and learner control, should be expioited selectively - particularly at the stages of integration and testing of business knowledge.

- CAI investment should be based on enhancing rather than replacing traditional learning mechanisms.

The unique features of CAI in a business school environment relate to enrichment of the learning process rather than replacement of existing mexhanisms. Investment decisions should take this view rather than that of a cost reduction exercise.

- CAI activity should mirror the computer-based business environment.

The use of computers on an MBA programme offers a unique opportunity for managers and porential managets to experience the new world of computerized business in a risk-free environment. Learning techniques and activities should build on this in the knowledge that long-term perceptions of the value of computers are being formed.

\section{Conclusion}

With the recent acquisition of new computing facilities the Graduate School of Business now faces an ongoing series of decisions regarding their optimal use on the MBA programme. The wisdom of these decisions will have great impact not only on the effectiveness of MBA instruction, but on the perceptions of graduating students regarding computers and their application in business. With this in mind, it has been essential to formulate and apply a cohesive policy that takes into account the unique atributes of computer-aided instruction and its selective application to the learning process in higher education.

\section{References}

I. Chambers, J.A. \& Sprectier. J.W. Compurer assissed instruction: Current trends and critical issues. Communications of the ACM. June 1980, Vol.23, pp.332 - 34?

2. Barker, P. Book Review: Hawkins. C.A. Computer based learning - A survey of the factors influencing its initiation and devetopment. Programmed Leaming and Educotional Technologi, May 19.8. Vol.15. pp.88-89.

3. Leiblum. M.D. Factors somerimes overlooked and underestimated in the selection and suceess of CAL as an instructional medium. In Lewis, R. \& Tage, D. (Eds.). Computers in Education. Amserdam: Nont-Holland Publishing Company. 1981. pp.2- 284 .

4. What is CONDLIT?. CONDLIT. Liniversity of lowa. P.O. Box 388. Iowa City. Iova 5224.

5. Ratart. J.F. \& Suol Morion, M.S. Computers and the Learning Process in Higher Edwcation. New York: MoGraw-Hill. 1975. pp.19- 30 .

6. Kolb. D.A. Indisidual learning styles and the learning process. Honking Paper 535-71. Sban School of Management, MIT, Cambridge. Mass.. Spring 1951.

- Hilgard. E.R. Theories of Learning, Englewood Cliffs NJ: Prentice Hall Inc., 19s.

8. Wercheimer. M. Gestaht theory of leaming. In Gazda, G.M. \& Corsini. R.j., Theories of Learning. Itasca. Illinois: R.E. Peacoct Pubticarions. 1980. 